\title{
Prostate Stem Cells and Cancer Stem Cells
}

\author{
Jia J. Li $i^{1,2,3,4,5}$ and Michael M. Shen ${ }^{1,2,3,4,5}$ \\ ${ }^{1}$ Department of Medicine, Columbia University College of Physicians and Surgeons, New York, \\ New York 10032 \\ ${ }^{2}$ Department Genetics and Development, Columbia University College of Physicians and Surgeons, New York, \\ New York 10032 \\ ${ }^{3}$ Department of Urology, Columbia University College of Physicians and Surgeons, New York, New York 10032 \\ ${ }^{4}$ Department of Systems Biology, Columbia University College of Physicians and Surgeons, New York, \\ New York 10032 \\ ${ }^{5}$ Herbert Irving Comprehensive Cancer Center, Columbia University College of Physicians and Surgeons, \\ New York, New York 10032 \\ Correspondence: mshen@columbia.edu
}

Stem/progenitor cells play central roles in processes of organogenesis and tissue maintenance, whereas cancer stem cells (CSCs) are thought to drive tumor malignancy. Here, we review recent progress in the identification and analysis of normal prostate stem/progenitor cells as well as putative CSCs in both genetically engineered mouse models as well as in human tissue. We also discuss studies that have investigated the cell type of origin for prostate cancer. In addition, we provide a critical assessment of methodologies used in stem cell analyses and outline directions for future research.

P rostate cancer displays significant intertumor heterogeneity as tumors of apparently similar histopathology ranging in disease severity from indolent to aggressive forms. Notably, patients with low- to intermediate-grade localized prostate cancer can have widely different outcomes, ranging from indolent tumors that can be monitored by active surveillance to highly aggressive disease that requires treatment (Thompson et al. 2013; Siegel et al. 2018). Androgen deprivation represents the major therapeutic strategy for aggressive prostate cancer, but many treated tumors will relapse and progress to castration-resistant prostate cancer (CRPC). Following treatment with second- generation anti-androgens such as abiraterone and enzalutamide, the extent and duration of response are variable, with many tumors eventually progressing to lethal disease (Watson et al. 2015).

A popular explanation for the origin of intertumor heterogeneity in cancer is provided by the "cell of origin" model, which posits that differences in the normal cell type that undergoes oncogenic transformation give rise to distinct tumor subtypes that differ in histopathological and molecular properties as well as treatment response and disease outcome (Fig. 1). During normal tissue homeostasis, stem/progenitor cells are defined by two key properties: self-renewal

Editors: Michael M. Shen and Mark A. Rubin

Additional Perspectives on Prostate Cancer available at www.perspectivesinmedicine.org

Copyright (C) 2019 Cold Spring Harbor Laboratory Press; all rights reserved; doi: 10.1101/cshperspect.a030395

Cite this article as Cold Spring Harb Perspect Med 2019;9:a030395 
J.J. Li and M.M. Shen

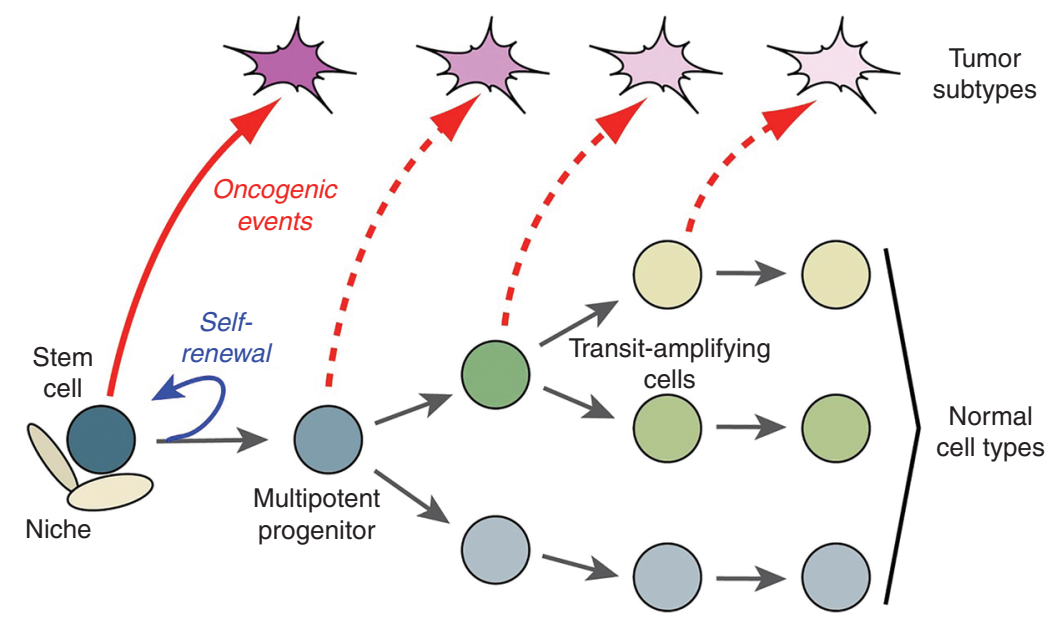

Figure 1. Lineage hierarchy and cell types of origin for cancer. Schematic representation of simple lineage hierarchy within an epithelial tissue. Distinct normal cell types arise from a stem cell that is capable of selfrenewal and multipotency, under the influence of a stem cell niche. Different tumor subtypes may arise from oncogenic transformation of the stem cell or non-stem cells within the lineage hierarchy. (From Shibata and Shen 2013; adapted, with permission, from the authors.)

and multipotency, which is the ability to generate distinct cell types through a defined lineage hierarchy (Blanpain and Fuchs 2014; Visvader and Clevers 2016). The fundamental ability of tissue stem cells to undergo long-term selfrenewal makes them a compelling target for oncogenic transformation. Indeed, there is considerable evidence that stem cells often represent the cell of origin for cancer in a wide range of solid tumors (Visvader 2011; Blanpain 2013; Sutherland and Visvader 2015). However, other cell types within the lineage hierarchy can also potentially serve as cell types of origin and may generate a range of tumor subtypes. Therefore, the identification of normal stem/progenitor cells and understanding of lineage relationships is critical for understanding tumor initiation and has potential translational implications.

Prostate cancer also displays significant intratumor heterogeneity throughout its progression from localized to advanced metastatic disease. In particular, primary prostate tumors typically harbor pathologically and genetically distinct foci (Boutros et al. 2015; Cooper et al. 2015). Genomic analyses of prostate cancer have also revealed significant intratumor heterogeneity at the level of mutations and chromosomal rearrangements. Moreover, genomic sequencing of secondary metastases has shown their subclonal heterogeneity (Gundem et al. 2015; Hong et al. 2015).

The origin and persistence of intratumor heterogeneity can potentially be explained by the "cancer stem cell" (CSC) model (Kreso and Dick 2014; Batlle and Clevers 2017). In this model, tumorigenic cells with stem cell features can self-renew to propagate the tumor and can also generate nontumorigenic cells that are unable to propagate the tumor, thereby generating heterogeneity. Thus, a subpopulation of CSCs might reside at the top of a lineage hierarchy within a tumor. Such putative CSCs would presumably drive tumor malignancy as well as relapse and therefore represent desirable targets for therapy. Moreover, clonal evolution of CSCs could potentially generate multiple tumor populations with distinct genetic profiles that could independently propagate to maintain tumor heterogeneity.

Below, we describe how studies of prostate stem cells, cell types of origin, and CSCs may provide insights into the pathogenesis and treatment of prostate cancer, focusing on recently published work. Detailed descriptions of earlier 
Prostate Stem Cells and Cancer Stem Cells

work can be found in several excellent reviews (Wang and Shen 2011; Xin 2013; Lee and Shen 2015; Rybak et al. 2015; Shibata and Shen 2015; Skvortsov et al. 2018).

\section{CELL TYPES OF THE PROSTATE EPITHELIUM}

The mouse and human prostate contain a pseudostratified epithelium that is composed of three primary cell types (Shen and Abate-Shen 2010; Toivanen and Shen 2017). Luminal cells are tall columnar secretory cells that express cytokeratins (CK) 8 and 18 and high levels of androgen receptor (AR). Basal cells are adjacent to the basement membrane and express CK5 and CK14 as well as p63 but have low or undetectable levels of AR. There is also a population of "intermediate" cells that are basally localized and co-express basal and luminal markers (De Marzo et al. 1998; Wang et al. 2013), but it is unclear whether these cells represent a distinct cell type or instead correspond to a transition between basal and luminal states. Finally, neuroendocrine cells are a rare cell type that expresses markers such as synaptophysin and chromogranin A and are sparsely populated within the prostate epithelium.

Unlike tissues such as the intestine, the adult prostate epithelium undergoes extremely slow turnover during homeostasis. The limited proliferation in the adult mouse prostate primarily occurs in luminal cells, with a minority of proliferating cells in the basal compartment (Wang et al. 2013). However, following systemic androgen deprivation caused by chemical or surgical castration, the prostate will regress to $\sim 10 \%$ of its hormonally intact size, primarily because of death of luminal cells (Evans and Chandler 1987; Isaacs et al. 1992). On re-administration of androgens at physiological levels, the regressed prostate will fully regenerate to the size found in the hormonally intact state. Serial prostate regression and regeneration can be experimentally induced for more than 30 cycles in rodents (Isaacs 1985; Tsujimura et al. 2002), implying the existence of a castration-resistant stem cell population(s) in the regressed prostate epithelium.

\section{ASSAYS FOR IDENTIFYING NORMAL AND TUMORIGENIC PROGENITOR CELLS}

Multiple experimental assays have been used for the identification of prostate stem cells as well as CSCs. However, the results may often be assay-dependent, yielding evidence for different stem/progenitor populations, and thereby leading to confounding findings in the literature. Consequently, it is essential to understand the key limitations of each assay so that experimental findings can be properly placed in a broader context.

There are three general categories of functional assays for the identification of progenitor cells in the normal as well as transformed prostate epithelium (Fig. 2). First, cell culture assays have historically used sphere formation ("prostaspheres") in suspension culture to evaluate the self-renewal and differentiation potential of cell populations isolated by flow cytometry (Lawson et al. 2007; Xin et al. 2007). However, sphere-formation assays have been limited by the inability of prostate luminal cells, including adenocarcinoma cells, to grow and differentiate under the conditions used (Garraway et al. 2010). More recently, organoid culture approaches have been developed to overcome this limitation, supporting the growth and propagation of normal and transformed luminal cells (Chua et al. 2014; Gao et al. 2014; Karthaus et al. 2014).

A second major approach uses a tissue reconstitution and renal grafting approach to evaluate the regenerative capacity of normal prostate epithelial populations (Xin et al. 2003; Cunha 2008). This approach combines dissociated prostate epithelial cells with embryonic urogenital sinus mesenchyme (UGSM) ex vivo, followed by renal grafting into immunodeficient mice in vivo and analysis of the resulting tissue. This tissue reconstitution strategy is versatile and has the advantage of generating normal or transformed prostate tissue that can be analyzed by histopathological and molecular approaches. However, this approach is limited by the use of UGSM, which is required for its inductive properties, and alternative stromal components that can fully substitute in this assay have not yet 
J.J. Li and M.M. Shen
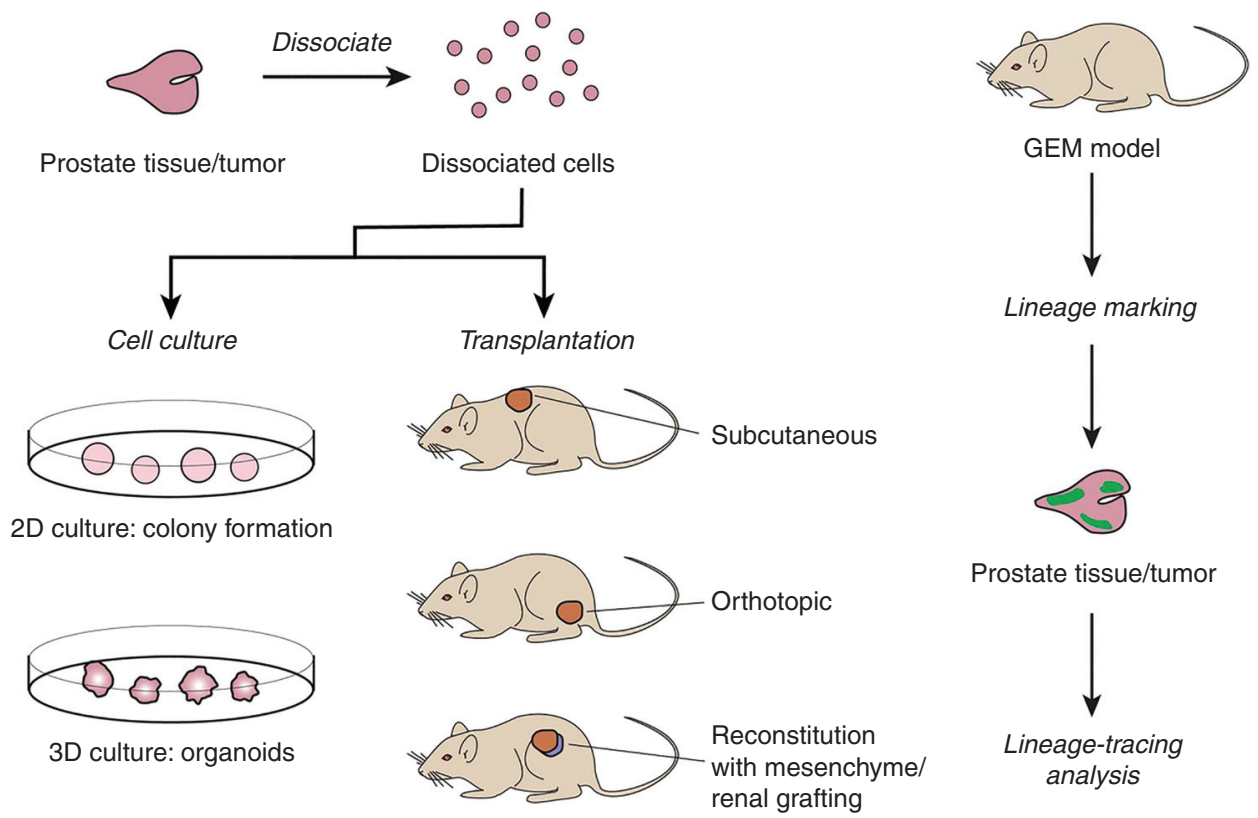

Prostate tissue/tumor

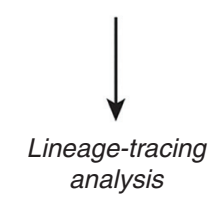

Figure 2. Different types of functional assays for prostate stem cells and cancer stem cells. (Left) In cell culture assays, dissociated cells from normal prostate tissue or prostate tumors can be examined for their ability to form colonies in two-dimensional (2D) culture or to form organoids in three-dimensional (3D) culture. In xenografting assays, dissociated tumor cells can be grafted subcutaneously or orthotopically. Alternatively, tissue reconstitution using dissociated normal or tumor cells involves recombination with embryonic urogenital sinus mesenchyme (UGSM) followed by grafting under the renal capsule. (Right) Lineage tracing in genetically engineered mouse (GEM) models involves the creation of a genetic lineage mark, often using inducible Cre recombinase, followed by analysis of marked tissue (indicated in green) to ascertain lineage relationships. (From Shibata and Shen 2015; adapted, with permission, from the authors.)

been identified. In the context of tumors, similar tissue reconstitution approaches using UGSM have been adopted to assay tumor-initiating abilities, in addition to more standard xenografting approaches involving subcutaneous or orthotopic implantation of tumor cells without UGSM. In all of these cases, serial transplantation can also be performed to investigate longterm propagation of tissues by normal or transformed progenitors.

Finally, lineage tracing in vivo represents a third strategy that uses genetically engineered mice in which expression of Cre recombinase within a defined cell population can be used to indelibly mark cells with expression of a suitable reporter, such as a fluorescent protein, allowing the tracing of the progeny of the marked cells (Alcolea and Jones 2013). This approach has key advantages as it is performed entirely in vivo, within the endogenous tissue microenvironment. However, important caveats include the need to validate that the Cre drivers used specifically label the desired cell populations, the frequent lack of desired Cre drivers, as well as the potential effects of tamoxifen (often used to activate inducible Cre drivers) on cell type differentiation. An alternative method is provided by tetracycline-regulated systems for cell marking, which have been widely used in studies of other tissues; however, tetracycline-regulated systems have been less commonly used in studies of the prostate.

In addition to functional assays, other types of assays have been used to characterize putative prostate progenitors. Notably, label-retention assays have been used to identify long-lived quiescent cells within the prostate, typically using a pulse-chase strategy involving an initial labeling 
of newly synthesized DNA with BrdU (Tsujimura et al. 2002) or of nucleosomes with histones fused with green fluorescent protein (GFP) (Zhang et al. 2018). However, studies in other tissues have shown that label retention is not an inherent property of stem cell populations (e.g., Kiel et al. 2007), and thus the interpretation of label-retention assays are fraught with potential difficulties.

For analyses of the human prostate, cell culture and tissue recombination-based approaches have been used, but genetic lineage tracing as performed in genetically engineered mice is not feasible. However, several studies have shown that normal lineage hierarchies can be reconstructed based on mapping of cell clusters that contain mitochondrial DNA alterations in human prostate tissue (Blackwood et al. 2011; Gaisa et al. 2011). Using this approach, computational analyses of deduced clonal patterns in serial reconstructs of sectioned tissue have inferred potential lineage relationships (Moad et al. 2017).

\section{CELL TYPE SPECIFICATION DURING PROSTATE ORGANOGENESIS}

During organogenesis, progenitor cells can be identified as multipotent or unipotent cells that arise in tissue anlage and give rise to the bulk of the tissue. The lineage relationships within the prostate epithelium during organogenesis have been studied in some detail, but important issues remain to be clarified (Toivanen and Shen 2017). Notably, the earliest stages of prostate organogenesis in the mouse occur in late fetal development, although most prostate growth occurs during postnatal stages that are more readily accessible for experimentation (e.g., through organ culture approaches). In the human, comparable analyses have been limited because of the inaccessibility of the fetal stages in which prostate organogenesis occurs.

One key question has been the role of basal progenitors in prostate epithelial specification. Several studies have used Trp63 null mutant mice as well as lineage tracing to show that Trp63 is essential for prostate formation and that p63-positive basal cells are multipotent, giv- ing rise to basal, luminal, and neuroendocrine cells (Signoretti et al. 2000, 2005; Pignon et al. 2013). In contrast, a tissue rescue experiment using grafted Trp63 null mutant urogenital sinus to generate prostate tissue lacking basal cells indicated that basal cells are not essential for luminal and neuroendocrine specification (Kurita et al. 2004).

Lineage-tracing experiments performed during organogenesis have shown the existence of multipotent basal progenitors that give rise to basal, luminal, and neuroendocrine cells during the first four weeks of postnatal development (Ousset et al. 2012). These conclusions have been further supported by multicolor lineage tracing as well as quantitative analyses (Wuidart et al. 2016). In contrast, luminal progenitors during organogenesis appear to be unipotent, giving rise only to luminal cells (Ousset et al. 2012; Wuidart et al. 2016).

Finally, the origin of prostate neuroendocrine cells during organogenesis has not been completely resolved. Although several studies have supported an epithelial origin of neuroendocrine cells (Goldstein et al. 2008; Ousset et al. 2012), there have also been reports that neuroendocrine cells arise from the caudal neural crest (Szczyrba et al. 2017). The basis for these discrepant results remains unclear.

\section{ADULT PROGENITOR CELLS}

The identities of progenitor cells in the normal adult mouse prostate have been explored extensively by lineage-tracing analyses using inducible Cre drivers that are specific for basal or luminal compartments. These studies have shown that both the luminal and basal compartments are largely maintained during tissue homeostasis by unipotent progenitors (Choi et al. 2012; Lu et al. 2013; Wang et al. 2013), although the existence of rare bipotent progenitors cannot be excluded. Instead, bipotent progenitors have been more readily detected in ex vivo assays or in vivo during tissue repair or regeneration. Moreover, the detection of such progenitors may be further complicated by their potential nonuniform distribution within the prostate epithelium. 


\section{Localization of Prostate Progenitors}

Several lines of evidence have suggested that prostate progenitors display nonuniform distribution within the prostate epithelium. In particular, studies in both mouse and human have indicated that prostate stem cells are enriched in the proximal-most region of the prostate ducts, which is closest to the urethra. Thus, analysis of BrdU label retention during serial androgen-mediated regression and regeneration has shown that label-retaining cells are highly enriched in the proximal ducts and correspond to both basal and luminal cells (Tsujimura et al. 2002). Further studies have shown that the proximal region has greater ability to propagate in grafts following serial transplantation, suggesting the presence of progenitor cells with self-renewal capability (Goto et al. 2006). In addition, more recent studies have also suggested a proximal location of luminal progenitors (Kwon et al. 2016; Zhang et al. 2018). Mathematical modeling of human prostate lineages that were reconstructed on the basis of spatial patterns of mitochondrial mutations have also indicated a proximal location of multipotent basal cells (Moad et al. 2017). In contrast, however, rapidly dividing cells were found at ductal tips of prostate ducts during both organogenesis and regeneration, suggesting that at least some progenitor function is localized distally during prostate growth (Sugimura et al. 1986).

\section{Basal Progenitor Cells}

Cell culture and tissue reconstitution approaches have been used extensively to investigate the stem/progenitor properties of basal cell populations isolated by flow cytometry. Notably, several studies have used cell surface markers to enrich for basal cells that have increased sphere-forming ability and to generate prostate in tissue reconstitution assays. For example, Sca- $1^{+} \mathrm{CD} 49 \mathrm{f}^{\text {high }}$ cells isolated by flow cytometry from dissociated mouse prostate displayed sphere-forming ability and could readily reconstitute prostate tissue following recombination with embryonic urogenital mesenchyme in renal grafts (Lawson et al. 2007). Similar approaches to isolate Trop2 $2^{+} \mathrm{CD} 49 \mathrm{f}^{\text {high }}$ cells have been used to identify populations of mouse and human basal cells that display sphere-forming and tissue reconstitution activities (Goldstein et al. 2008). These grafts contained luminal, basal, and neuroendocrine cells, suggesting the multipotency of the basal progenitors in this assay (Goldstein et al. 2008). Similar assays have also been used to investigate functional activities of putative stem cell regulatory genes such as Bmi-1 (Lukacs et al. 2010). In addition, markers such as integrin $\alpha_{2} \beta_{1}$ (Collins et al. 2001) and CD133 (Richardson et al. 2004) have been used to identify candidate human prostate stem cell populations, which are likely to reside in the basal compartment. At present, it is unknown whether the basal cells isolated from normal prostate in these studies represent specific subsets of basal cells with progenitor properties, or whether their ex vivo progenitor properties represent general attributes of most or all prostate basal cells.

In contrast, there is considerable evidence for the existence of bipotential basal cells during androgen-mediated regeneration as well as during tissue repair. Thus, Lgr5-positive basal cells have been identified as a bipotent progenitor population during prostate regeneration (Wang et al. 2015). Other studies have examined the occurrence of asymmetric divisions, which correlate with bipotential basal progenitor activity, and have shown their occurrence during organogenesis as well as during androgen-mediated tissue regeneration (Wang et al. 2014a). Finally, basal-to-luminal differentiation has been shown to occur in contexts of tissue repair following epithelial damage or inflammation (Kwon et al. 2014; Toivanen et al. 2016), in which basal progenitors can generate luminal cells to replace those lost as a result of tissue damage. This plasticity of basal cells may account for their reported activities in ex vivo stem cell assays, which may mimic conditions of tissue damage and repair.

\section{Luminal Progenitor Cells}

In contrast with normal tissue homeostasis, lineage-tracing studies have suggested that luminal 
cells can possess progenitor activities during androgen-mediated regeneration. Notably, a rare population of castration-resistant $\mathrm{Nkx} 3.1$ expressing cells (CARNs) in the regressed prostate displayed bipotent progenitor activity during regeneration in vivo and could also reconstitute prostate tissue in grafts (Wang et al. 2009). More recently, distinct luminal progenitors expressing Bmi-1 have also been described during prostate regeneration (Yoo et al. 2016). Although these two populations are nonoverlapping, both of these stem/progenitors are likely to be facultative, arising in the context of tissue regeneration.

Initial studies of prostate luminal cells ex vivo suggested that luminal cells lacked progenitor properties, most likely because of their poor survival after tissue dissociation under many assay conditions. However, recent advances in three-dimensional organoid culture have described conditions that allow the growth and proliferation of luminal cells in culture, including bipotent luminal progenitors from mouse and human prostate (Chua et al. 2014; Karthaus et al. 2014). In addition, organoids could be generated from single CARNs, consistent with their progenitor capabilities (Chua et al. 2014). Subsequent studies have indicated the existence of both bipotent and unipotent luminal progenitors in organoid culture; the bipotent progenitors could generate organoids that can propagate indefinitely during serial passaging in organoid culture, whereas the unipotent luminal-committed organoids had a limited self-renewal capability (Agarwal et al. 2015).

Recent studies have investigated the properties of subsets of luminal cells isolated by flow cytometry. In the mouse prostate, the $\mathrm{Sca} 1^{+} \mathrm{CD} 49 \mathrm{f}^{\text {low }}$ population was shown to be enriched for luminal progenitors that are bipotential in organoid culture as well as in tissue reconstitution assays (Kwon et al. 2016). In addition, CD $38^{\text {low }}$ luminal cells from the human prostate were shown to have a high efficiency of organoid formation and could generate prostate ducts in a tissue reconstitution assay (Liu et al. 2016). Most recently, a label-retaining luminal population has been identified by pulse-chase expression of a H2B-GFP fusion protein, which also allows isolation of the GFP-expressing cells (Zhang et al. 2018). These label-retaining cells were castration-resistant and displayed bipotency in organoid and tissue reconstitution assays (Zhang et al. 2018). At present, the relationship of these luminal subsets to each other is unknown, but overall these findings suggest that the luminal compartment is heterogeneous in both the mouse and human prostate.

\section{CELL TYPES OF ORIGIN FOR PROSTATE CANCER}

In many tumor types, analyses of cell types of origin have focused on understanding the genesis of distinct tumor subtypes. However, despite the considerable intertumor heterogeneity of prostate cancer, it has been difficult to stratify prostate adenocarcinoma into distinct tumor subtypes at either the histopathological or molecular level. Consequently, many studies have focused on resolving whether differences in tumor aggressiveness may be related to the cell type of origin. Understanding such differences is of considerable translational significance because low- to intermediate-grade localized prostate cancer can lead to a wide range of outcomes (Thompson et al. 2013), yet the molecular basis of these distinct outcomes is poorly understood.

Studies of the cell of origin for prostate cancer have used two types of experimental approaches, involving either in vivo lineage tracing or ex vivo methods in which normal cell types are isolated and then undergo oncogenic transformation in culture or in grafts. These studies have underscored that the phenotype of a given prostate tumor may not be informative regarding its cell type of origin. In particular, during the progression of prostate cancer from the precursor stage known as prostatic intraepithelial neoplasia (PIN) to adenocarcino$\mathrm{ma}$, there is a complete loss of basal cells, resulting in the luminal phenotype of prostate cancer. In principle, however, basal cells can represent a cell of origin for prostate cancer if they subsequently undergo differentiation into a luminal phenotype. 


\section{In Vivo Studies}

Lineage-tracing studies in genetically engineered mouse models have provided evidence that prostate cancer can arise from both basal and luminal cells in vivo. Inducible deletion of the Pten tumor suppressor in either basal or luminal cells in vivo resulted in high-grade PIN and adenocarcinoma, with Pten loss in basal cells leading to basal-to-luminal differentiation, giving rise to tumors with a luminal phenotype (Choi et al. 2012; Wang et al. 2013). Notably, bioinformatic comparison of tumors arising from Pten deletion in basal versus luminal cells showed that the luminal-origin tumors were more aggressive and identified a molecular signature that could stratify human prostate tumors with different clinical outcomes (Wang et al. 2013). These analyses have provided initial evidence supporting the "cell of origin" model for prostate cancer and are consistent with bioinformatic analyses of human patient cohorts that have categorized prostate tumors into distinct basal and luminal molecular subtypes (Zhao et al. 2017).

Subsequent studies have examined the cell of origin in several distinct mouse models of prostate cancer, including a hormonal carcinogenesis model, and have found that luminal cells are consistently observed as the cell of origin in vivo for each model examined (Wang et al. 2014b). Interestingly, other studies had found that basal cells could give rise to tumors after tissue dissociation and renal grafting (Taylor et al. 2012); because this was not observed in the context of the intact prostate, these findings are most likely due to the ability of basal cells to differentiate into luminal cells ex vivo (Wang et al. 2014b). Taken together, these results suggest a distinction between "cell of origin" and "cell of mutation," in which cell of mutation can be defined as a cell type that carries an oncogenic mutation but is not phenotypically transformed unless it can become a cell of origin (Liu et al. 2011). Such "cells of mutation" can appear to represent cells of origin in experimental contexts but would not correspond to authentic cells of origin in vivo. Consistent with a luminal cell of origin, other studies have shown that castration-resistant luminal progenitors identified in the regressed prostate can also serve as cells of origin (Wang et al. 2009; Yoo et al. 2016; Chua et al. 2018).

\section{Ex Vivo Studies}

Initial studies on cell of origin using ex vivo approaches focused on the ability of transformed basal cells to generate tumors. For example, co-activation of Akt and AR in mouse Sca $1^{+} \mathrm{CD} 49 \mathrm{f}^{\text {low }}$ cells or of AKT, ERG, and AR in human CD49f $\mathrm{f}^{\text {high }}$ Trop $2^{\text {high }}$ basal cells resulted in adenocarcinoma phenotypes in reconstituted grafts (Goldstein et al. 2010; Lawson et al. 2010). Furthermore, co-activation of N-MYC and AKT in human basal cells could lead to tumors with neuroendocrine phenotypes (Lee et al. 2016).

Although luminal cells displayed poor viability after tissue dissociation in these earlier studies, this limitation has been subsequently overcome through the use of novel culture approaches that allow analyses of the ability of luminal cells to undergo oncogenic transformation in culture. The development of organoid culture conditions that promote luminal cell survival and proliferation allowed the demonstration that specific Cre-mediated deletion of Pten and activation of oncogenic Kras in luminal cells resulted in tumor phenotypes (Chua et al. 2014). Furthermore, lentiviral-mediated overexpression of MYC and AKT in human $\mathrm{CD} 26^{+}$luminal cells in organoid culture followed by tissue reconstitution of the organoids with UGSM in renal grafts resulted in low-grade adenocarcinoma in vivo, suggesting that luminal cells can serve as a cell of origin for human prostate tumors (Park et al. 2016). Analogously, human $\mathrm{CD} 38^{\text {low }}$ luminal cells could be transformed by co-expression of MYC, AKT, and $\mathrm{AR}$ to generate prostate adenocarcinoma in tissue reconstitution assays (Liu et al. 2016). Similar results have been reported using a novel two-dimensional culture system (Zhang et al. 2017). Taken together, these recent findings reconcile a large body of previous results and indicate that luminal cells correspond to the predominant, if not exclusive, cell type of origin for prostate cancer. 
Prostate Stem Cells and Cancer Stem Cells

\section{IDENTIFICATION OF PROSTATE CANCER STEM CELLS}

The functional identification of CSCs depends on their ability to initiate tumors and give rise to both tumorigenic and nontumorigenic progeny, presumably through asymmetric cell divisions. These properties are typically examined in the context of a transplantation assay, and candidate CSCs can be further assessed for their ability to propagate tumors through serial transplantation. Thus, these assays seek to identify tumorinitiating cells (TICs) and tumor-propagating cells (TPCs), which in principle can be purified using appropriate cell surface markers to define specific cell populations. In practice, however, studies of prostate cancer have been limited by the low efficiency of xenotransplantation starting from primary human prostate tumors (Li et al. 2009), which has often precluded the identification of candidate CSC populations.

Given this difficulty, many studies have used cancer cell lines or xenografts established from cancer cell lines to investigate putative CSC populations. Using prostate cell lines or xenografts derived from these lines, numerous publications have identified cell surface markers that can be used in flow-sorting experiments to enrich for putative CSCs, including CD133, CD44, and $\alpha_{2} \beta_{1}$ integrin (Table 1 ); many of these markers have also been implicated in studies of normal stem cells in a range of epithelial tissues. However, results using several of these markers may vary depending on the specific cell lines analyzed or assays used, raising concerns as to whether they represent authentic markers of

Table 1. Commonly used candidate markers of prostate stem cells and cancer stem cells

\begin{tabular}{|c|c|c|}
\hline Marker & Description & Key reference(s) \\
\hline ABCG2 & $\begin{array}{l}\text { ATP-binding cassette }(\mathrm{ABC}) \text { transporter family } \\
\text { member that may be involved in multidrug } \\
\text { resistance. }\end{array}$ & $\begin{array}{l}\text { Gangavarapu et al. 2013; Samant et al. } \\
\text { 2015; also Patrawala et al. } 2005\end{array}$ \\
\hline ALDH & $\begin{array}{l}\text { Aldehyde dehydrogenase (ALDH) enzymatic } \\
\text { activity can be readily detected by Aldefluor } \\
\text { assay. }\end{array}$ & $\begin{array}{l}\text { Burger et al. 2009; van den Hoogen } \\
\text { et al. } 2010\end{array}$ \\
\hline CD44 & $\begin{array}{l}\text { Encodes cell adhesion molecule that is a receptor } \\
\text { for hyaluronic acid. Has multiple alternative } \\
\text { splice variants that result in distinct isoforms. }\end{array}$ & $\begin{array}{l}\text { Collins et al. 2005; Patrawala et al. 2006, } \\
2007\end{array}$ \\
\hline CD49f & $\begin{array}{l}\text { Also known as Itga6, encoding integrin } \alpha 6 \text { subunit. } \\
\text { Often used in combination with Sca-1 or Trop } 2 \\
\text { in flow-sorting studies. }\end{array}$ & $\begin{array}{l}\text { Lawson et al. 2007; Mulholland et al. } \\
\text { 2009; Sackmann Sala et al. } 2017\end{array}$ \\
\hline CD133 & $\begin{array}{l}\text { Also known as prominin } 1 \text {. Encodes pentaspan } \\
\text { transmembrane glycoprotein that has multiple } \\
\text { isoforms. }\end{array}$ & $\begin{array}{l}\text { Richardson et al. 2004; Collins et al. } \\
\text { 2005; Vander Griend et al. 2008; also } \\
\text { Wei et al. } 2016\end{array}$ \\
\hline CD166 & $\begin{array}{l}\text { Also known as ALCAM. Encodes transmembrane } \\
\text { glycoprotein. }\end{array}$ & Jiao et al. 2012 \\
\hline Integrin $\alpha_{2} \beta_{1}$ & $\begin{array}{l}\text { Integrin heterodimer that is a major receptor for } \\
\text { collagens. }\end{array}$ & $\begin{array}{l}\text { Collins et al. 2001, 2005; Patrawala et al. } \\
\text { 2007; also Toivanen et al. } 2011\end{array}$ \\
\hline Sca-1 & $\begin{array}{l}\text { Also known as Ly6a. Encodes an extracellular } \\
\text { glycosyl-phosphotidylinositol anchored protein } \\
\text { that is found in mouse but not human. Often } \\
\text { used in combination with markers such as } \\
\text { CD49f in flow-sorting studies. }\end{array}$ & $\begin{array}{l}\text { Burger et al. 2005; Xin et al. 2005; } \\
\quad \text { Lawson et al. 2007; Kwon et al. } 2016\end{array}$ \\
\hline Trop2 (Tacstd2) & $\begin{array}{l}\text { Also known as Tacstd2. Encodes transmembrane } \\
\text { glycoprotein that transduces intracellular } \\
\text { calcium signals. Often used in combination } \\
\text { with CD49f in flow-sorting experiments } \\
\text { with human cells. }\end{array}$ & Goldstein et al. 2008 \\
\hline
\end{tabular}


stem cells or CSCs. For example, recent studies of CD133 using lineage tracing in vivo indicate that it does not enrich for stemness in the normal mouse prostate (Wei et al. 2016).

Several studies using genetically engineered mouse models of prostate cancer have provided evidence for TICs with distinct properties, most notably phenotypes associated with an epithelial-mesenchymal transition (EMT). A basal-like phenotype of prostate CSCs was supported by the finding that $\mathrm{Sca}-1^{+} \mathrm{CD} 49 \mathrm{f}^{\text {high }}$ cells in a Pten mutant mouse model have tumor-initiating properties in tissue reconstitution assays (Mulholland et al. 2012). Other studies have shown that tumor cells that express a Vimentin-GFP reporter in a mouse model with Pten deletion and Kras activation display EMT phenotypes and show increased tumor-initiating properties in an orthotopic grafting assay (Ruscetti et al. 2015). These findings are of particular interest given the potential roles of EMT in castration resistance as well as tumor plasticity (Li et al. 2014).

In contrast, other studies have implicated luminal tumor cells as prostate CSCs. For example, luminal cells isolated as Sca- $1^{+} \mathrm{CD} 49 \mathrm{f}^{\mathrm{med}}$ cells from Pten mutant and Hi-Myc mouse models were found to be highly proliferative and display tumor-initiating properties in tissue reconstitution assays (Sackmann Sala et al. 2017). Similarly, luminal cells isolated from a Pten;Trp53 mouse model generated tumor organoids with multilineage differentiation as well as a second type of tumor organoid that only contained luminal tumor cells (Agarwal et al. 2015). Interestingly, after subcutaneous grafting into immunodeficient mice, the multilineage organoids generated tumors with adenosquamous histology, whereas the luminal-only organoids formed adenocarcinoma (Agarwal et al. 2015). These findings suggest the existence of two types of luminal TPCs that are arranged in a hierarchical relationship, with multipotent CSCs that can give rise to unipotent luminal-committed progenitors.

A similar hierarchical relationship of distinct prostate TPC types has been suggested by ex vivo assays. Transformation of human Trop $2^{+} \mathrm{CD} 49 \mathrm{f}^{\text {high }} \mathrm{CD} 26^{-}$basal cells with MYC and AKT followed by tissue reconstitution resulted in the generation of heterogeneous adenosquamous tumors that contained both basal-like and luminal-like TPCs (Stoyanova et al. 2013). Notably, the basal-like CD49f ${ }^{\text {high }}$ TPCs gave rise to tumors with mixed squamous and adenocarcinoma histology after serial transplantation, whereas the luminal-like $\mathrm{CD} 49 \mathrm{f}^{\text {low }}$ TPCs strictly generated tumors with adenocarcinoma histology (Stoyanova et al. 2013), again consistent with a lineage hierarchy in which multipotent CSCs give rise to unipotent progenitors.

Interestingly, analyses of human prostate cancer cell lines and xenografts have also identified two distinct tumor-propagating populations based on differential expression of prostate-specific antigen (PSA) that may be related by asymmetric divisions. Imaging of individual LNCaP prostate cancer cells that express low or absent levels of prostate-specific antigen $\left(\mathrm{PSA}^{-/ \mathrm{low}}\right.$ ) showed that they can undergo asymmetric cell division to generate $\mathrm{PSA}^{+}$cells, whereas in xenografts $\mathrm{PSA}^{-/ \text {low }}$ cells were castration-resistant and could drive long-term tumor propagation in serial transplantation assays (Qin et al. 2012). In contrast, $\mathrm{PSA}^{+}$cells had increased tumorinitiating ability relative to $\mathrm{PSA}^{-/ \mathrm{low}}$ cells in the first xenograft generation, but were less able to sustain long-term serial propagation in subsequent passages (Qin et al. 2012). However, the $\mathrm{PSA}^{- \text {low }}$ population is strikingly heterogeneous, with the ALDH ${ }^{\text {high }} \mathrm{CD} 44^{+} \alpha_{2} \beta_{1}^{+}$ subpopulation highly capable of giving rise to castration-resistant tumors and serial propagation in androgen-ablated host mice (Chen et al. 2016). Interestingly, asymmetric divisions in which $\mathrm{PSA}^{- \text {low }}$ cells generate a $\mathrm{PSA}^{+}$daughter also showed differential segregation of Numb (Qin et al. 2012), a putative cell fate determinant that has been implicated in asymmetric divisions in multiple systems (Bajaj et al. 2015). Consistent with this finding, $\mathrm{Numb}^{-/ \mathrm{low}}$ cells isolated from a range of prostate cancer cell lines had increased tumor initiation relative to $\mathrm{Numb}^{+}$cells, and displayed greater castration resistance (Guo et al. 2017).

Recent advances in optimization of conditions for establishment of patient-derived xeno- 
grafts have provided promising new approaches for assaying tumor initiation by human prostate cancer cells (Toivanen et al. 2013). In principle, the analysis of such grafts could allow the direct assessment of putative CSC markers using primary human prostate tumors. Interestingly, this approach has shown that expression of integrin $\alpha_{2} \beta_{1}$ does not enrich for tumor-initiating ability in human prostate xenografts (Toivanen et al. 2011).

\section{CONCLUDING PERSPECTIVES}

Despite many promising results, it still remains unclear whether CSCs exist in some or all human prostate tumors and whether the overall concept has translational significance. One key difficulty has been that several widely used candidate CSC markers have generated inconsistent results in differing experimental systems. Another difficulty has been to demonstrate that putative CSCs can generate both tumorigenic as well as nontumorigenic cells, as candidate nontumorigenic populations are often defined by the absence of markers and may be contaminated by poorly viable cells in experimental assays. Furthermore, the heterogeneity of tumor cell types following transplantation of putative CSCs may arise from the reconstitution of a lineage hierarchy but may alternatively be caused by the transplantation of a tumor cell population that is genetically heterogeneous. Notably, lineage-tracing approaches have been used successfully in other tumor types to provide definitive evidence for CSC populations (Chen et al. 2012; Driessens et al. 2012; Schepers et al. 2012) but have not yet been used in studies of genetically engineered mouse models of prostate cancer.

Several major technical issues remain in the analysis of putative human prostate stem cells and CSCs. One major hurdle has been the maintenance of viable luminal prostate cells after tissue dissociation. In part, these limitations can be overcome by continued development of organoid culture conditions that can maintain the luminal phenotype of human prostate tumor cells in culture (Beshiri et al. 2018). Notably, organoid culture approaches are promising because patient-derived organoids established from other solid tumors can recapitulate the histopathological and molecular diversity of patient samples (van de Wetering et al. 2015; Lee et al. 2018; Sachs et al. 2018). Another technical issue frequently associated with experimental analyses of putative prostate stem cells and CSCs involves the use of embryonic urogenital mesenchyme in tissue reconstitution assays. The urogenital mesenchyme provides a supporting stromal microenvironment for epithelial cells in such assays but also produces a complex mixture of largely uncharacterized signaling molecules that are potent inducing factors during prostate organogenesis. Furthermore, xenotransplantation assays generally require the use of immunodeficient rodent hosts, and consequently the roles of immune components in mediating tumorigenic activities of putative CSCs have not yet been evaluated.

Further studies of prostate stem cells and CSCs are likely to provide key insights into topics with profound translational significance. Notably, plasticity of CSCs may play a central role in the evolution of tumor phenotypes during prostate cancer progression and response to therapy. For example, neuroendocrine differentiation of CRPC in response to antiandrogen treatments arises by transdifferentiation of luminal tumor cells (Zou et al. 2017) and may be driven by CSC plasticity (Davies et al. 2018). Understanding the molecular basis for stem cell and CSC plasticity is therefore likely to yield novel findings that can advance the development of patient therapies.

\section{ACKNOWLEDGMENTS}

We apologize to many colleagues whose work has not been cited because of space constraints. We thank Francesco Cambuli, Mark Rubin, and Maho Shibata for helpful comments on the manuscript. Work on prostate development and cancer in the Shen laboratory has been supported by grants from the National Institutes of Health (NIH) (CA196662 and CA211024) and by a grant from the Department of Defense (DOD) Prostate Cancer Research Program (PC150051). 
J.J. Li and M.M. Shen

\section{REFERENCES}

Agarwal S, Hynes PG, Tillman HS, Lake R, Abou-Kheir WG, Fang L, Casey OM, Ameri AH, Martin PL, Yin JJ, et al. 2015. Identification of different classes of luminal progenitor cells within prostate tumors. Cell Rep 13: 2147-2158.

Alcolea MP, Jones PH. 2013. Tracking cells in their native habitat: Lineage tracing in epithelial neoplasia. Nat Rev Cancer 13: 161-171.

Bajaj J, Zimdahl B, Reya T. 2015. Fearful symmetry: Subversion of asymmetric division in cancer development and progression. Cancer Res 75: 792-797.

Batlle E, Clevers H. 2017. Cancer stem cells revisited. Nat Med 23: 1124-1134.

Beshiri ML, Tice CM, Tran C, Nguyen HM, Sowalsky AG, Agarwal S, Jansson KH, Yang Q, McGowen KM, Yin J, et al. 2018. A PDX/organoid biobank of advanced prostate cancers captures genomic and phenotypic heterogeneity for disease modeling and therapeutic screening. Clin Cancer Res 24: 4332-4345.

Blackwood JK, Williamson SC, Greaves LC, Wilson L, Rigas AC, Sandher R, Pickard RS, Robson CN, Turnbull DM Taylor RW, et al. 2011. In situ lineage tracking of human prostatic epithelial stem cell fate reveals a common clonal origin for basal and luminal cells. J Pathol 225: 181-188.

Blanpain C. 2013. Tracing the cellular origin of cancer. Nat Cell Biol 15: 126-134.

Blanpain C, Fuchs E. 2014. Stem cell plasticity. Plasticity of epithelial stem cells in tissue regeneration. Science 344: 1242281.

Boutros PC, Fraser M, Harding NJ, de Borja R, Trudel D Lalonde E, Meng A, Hennings-Yeomans PH, McPherson A, Sabelnykova VY, et al. 2015. Spatial genomic heterogeneity within localized, multifocal prostate cancer. Nat Genet 47: 736-745.

Burger PE, Xiong X, Coetzee S, Salm SN, Moscatelli D, Goto K, Wilson EL. 2005. Sca-1 expression identifies stem cells in the proximal region of prostatic ducts with high capacity to reconstitute prostatic tissue. Proc Natl Acad Sci 102: 7180-7185.

Burger PE, Gupta R, Xiong X, Ontiveros CS, Salm SN, Moscatelli D, Wilson EL. 2009. High aldehyde dehydrogenase activity: A novel functional marker of murine prostate stem/progenitor cells. Stem Cells 27: 2220-2228.

Chen J, Li Y, Yu TS, McKay RM, Burns DK, Kernie SG, Parada LF. 2012. A restricted cell population propagates glioblastoma growth after chemotherapy. Nature 488: 522-526.

Chen X, Li Q, Liu X, Liu C, Liu R, Rycaj K, Zhang D, Liu B Jeter C, Calhoun-Davis T, et al. 2016. Defining a population of stem-like human prostate cancer cells that can generate and propagate castration-resistant prostate cancer. Clin Cancer Res 22: 4505-4516.

Choi N, Zhang B, Zhang L, Ittmann M, Xin L. 2012. Adult murine prostate basal and luminal cells are self-sustained lineages that can both serve as targets for prostate cancer initiation. Cancer Cell 21: 253-265.

Chua CW, Shibata M, Lei M, Toivanen R, Barlow LJ, Bergren SK, Badani KK, McKiernan JM, Benson MC, Hibshoosh H, et al. 2014. Single luminal epithelial progenitors can generate prostate organoids in culture. Nat Cell Biol 16: 951-961.

Chua CW, Epsi NJ, Leung EY, Xuan S, Lei M, Li BI, Bergren SK, Hibshoosh H, Mitrofanova A, Shen MM. 2018. Differential requirements of androgen receptor in luminal progenitors during prostate regeneration and tumor initiation. eLife 7: e28768.

Collins AT, Habib FK, Maitland NJ, Neal DE. 2001. Identification and isolation of human prostate epithelial stem cells based on $\alpha_{2} \beta_{1}$-integrin expression. J Cell Sci 114: 3865-3872.

Collins AT, Berry PA, Hyde C, Stower MJ, Maitland NJ. 2005. Prospective identification of tumorigenic prostate cancer stem cells. Cancer Res 65: 10946-10951.

Cooper CS, Eeles R, Wedge DC, Van Loo P, Gundem G, Alexandrov LB, Kremeyer B, Butler A, Lynch AG, Camacho N, et al. 2015. Analysis of the genetic phylogeny of multifocal prostate cancer identifies multiple independent clonal expansions in neoplastic and morphologically normal prostate tissue. Nat Genet 47: 367-372.

Cunha GR. 2008. Mesenchymal-epithelial interactions: Past, present, and future. Differentiation 76: 578-586.

Davies AH, Beltran H, Zoubeidi A. 2018. Cellular plasticity and the neuroendocrine phenotype in prostate cancer. Nat Rev Urol 15: 271-286.

De Marzo AM, Meeker AK, Epstein JI, Coffey DS. 1998. Prostate stem cell compartments: Expression of the cell cycle inhibitor p27Kip1 in normal, hyperplastic, and neoplastic cells. Am J Pathol 153: 911-919.

Driessens G, Beck B, Caauwe A, Simons BD, Blanpain C. 2012. Defining the mode of tumour growth by clonal analysis. Nature 488: 527-530.

Evans GS, Chandler JA. 1987. Cell proliferation studies in the rat prostate: II. The effects of castration and androgeninduced regeneration upon basal and secretory cell proliferation. Prostate 11: 339-351.

Gaisa NT, Graham TA, McDonald SA, Poulsom R, Heidenreich A, Jakse G, Knuechel R, Wright NA. 2011. Clonal architecture of human prostatic epithelium in benign and malignant conditions. J Pathol 225: 172-180.

Gangavarapu KJ, Azabdaftari G, Morrison CD, Miller A, Foster BA, Huss WJ. 2013. Aldehyde dehydrogenase and ATP binding cassette transporter G2 (ABCG2) functional assays isolate different populations of prostate stem cells where ABCG2 function selects for cells with increased stem cell activity. Stem Cell Res Ther 4: 132.

Gao D, Vela I, Sboner A, Iaquinta PJ, Karthaus WR, Gopalan A, Dowling C, Wanjala JN, Undvall EA, Arora VK, et al. 2014. Organoid cultures derived from patients with advanced prostate cancer. Cell 159: 176-187.

Garraway IP, Sun W, Tran CP, Perner S, Zhang B, Goldstein AS, Hahm SA, Haider M, Head CS, Reiter RE, et al. 2010. Human prostate sphere-forming cells represent a subset of basal epithelial cells capable of glandular regeneration in vivo. Prostate 70: 491-501.

Goldstein AS, Lawson DA, Cheng D, Sun W, Garraway IP, Witte ON. 2008. Trop2 identifies a subpopulation of murine and human prostate basal cells with stem cell characteristics. Proc Natl Acad Sci 105: 20882-20887. 
Goldstein AS, Huang J, Guo C, Garraway IP, Witte ON 2010. Identification of a cell of origin for human prostate cancer. Science 329: 568-571.

Goto K, Salm SN, Coetzee S, Xiong X, Burger PE, Shapiro E, Lepor H, Moscatelli D, Wilson EL. 2006. Proximal prostatic stem cells are programmed to regenerate a proximaldistal ductal axis. Stem Cells 24: 1859-1868.

Gundem G, Van Loo P, Kremeyer B, Alexandrov LB, Tubio JM, Papaemmanuil E, Brewer DS, Kallio HM, Hognas G, Annala M, et al. 2015. The evolutionary history of lethal metastatic prostate cancer. Nature 520: 353-357.

Guo Y, Zhang K, Cheng C, Ji Z, Wang X, Wang M, Chu M, Tang DG, Zhu HH, Gao WQ. 2017. Numb ${ }^{-/ \mathrm{low}}$ enriches a castration-resistant prostate cancer cell subpopulation associated with enhanced Notch and Hedgehog signaling. Clin Cancer Res 23: 6744-6756.

Hong MK, Macintyre G, Wedge DC, Van Loo P, Patel K, Lunke S, Alexandrov LB, Sloggett C, Cmero M, Marass F, et al. 2015. Tracking the origins and drivers of subclonal metastatic expansion in prostate cancer. Nat Commun 6: 6605.

Isaacs JT. 1985. Control of cell proliferation and cell death in the normal and neoplastic prostate: A stem cell model. In Benign prostatic hyperplasia (ed. Rodgers $\mathrm{CH}$, et al.), pp. 85-94. Department of Health and Human Services, Washington, DC.

Isaacs JT, Lundmo PI, Berges R, Martikainen P, Kyprianou N, English HF. 1992. Androgen regulation of programmed death of normal and malignant prostatic cells. J Androl 13: 457-464.

Jiao J, Hindoyan A, Wang S, Tran LM, Goldstein AS, Lawson D, Chen D, Li Y, Guo C, Zhang B, et al. 2012. Identification of CD166 as a surface marker for enriching prostate stem/progenitor and cancer initiating cells. PLOS ONE 7: e42564.

Karthaus WR, Iaquinta PJ, Drost J, Gracanin A, van Boxtel R, Wongvipat J, Dowling CM, Gao D, Begthel H, Sachs N, et al. 2014. Identification of multipotent luminal progenitor cells in human prostate organoid cultures. Cell 159: 163-175.

Kiel MJ, He S, Ashkenazi R, Gentry SN, Teta M, Kushner JA, Jackson TL, Morrison SJ. 2007. Haematopoietic stem cells do not asymmetrically segregate chromosomes or retain BrdU. Nature 449: 238-242.

Kreso A, Dick JE. 2014. Evolution of the cancer stem cell model. Cell Stem Cell 14: 275-291.

Kurita T, Medina RT, Mills AA, Cunha GR. 2004. Role of p63 and basal cells in the prostate. Development 131: 49554964.

Kwon OJ, Zhang L, Ittmann MM, Xin L. 2014. Prostatic inflammation enhances basal-to-luminal differentiation and accelerates initiation of prostate cancer with a basal cell origin. Proc Natl Acad Sci 111: E592-E600.

Kwon OJ, Zhang L, Xin L. 2016. Stem cell antigen-1 identifies a distinct androgen-independent murine prostatic luminal cell lineage with bipotent potential. Stem Cells 34: 191-202.

Lawson DA, Xin L, Lukacs RU, Cheng D, Witte ON. 2007. Isolation and functional characterization of murine prostate stem cells. Proc Natl Acad Sci 104: 181-186.
Lawson DA, Zong Y, Memarzadeh S, Xin L, Huang J, Witte ON. 2010. Basal epithelial stem cells are efficient targets for prostate cancer initiation. Proc Natl Acad Sci 107: 2610-2615.

Lee SH, Shen MM. 2015. Cell types of origin for prostate cancer. Curr Opin Cell Biol 37: 35-41.

Lee JK, Phillips JW, Smith BA, Park JW, Stoyanova T, McCaffrey EF, Baertsch R, Sokolov A, Meyerowitz JG, Mathis C, et al. 2016. N-Myc drives neuroendocrine prostate cancer initiated from human prostate epithelial cells. Cancer Cell 29: 536-547.

Lee SH, Hu W, Matulay JT, Silva MV, Owczarek TB, Kim K, Chua CW, Barlow LJ, Kandoth C, Williams AB, et al. 2018. Tumor evolution and drug response in patientderived organoid models of bladder cancer. Cell 173: 515-528.

Li H, Jiang M, Honorio S, Patrawala L, Jeter CR, CalhounDavis T, Hayward SW, Tang DG. 2009. Methodologies in assaying prostate cancer stem cells. Methods Mol Biol 568: 85-138.

Li P, Yang R, Gao WQ. 2014. Contributions of epithelialmesenchymal transition and cancer stem cells to the development of castration resistance of prostate cancer. Mol Cancer 13: 55.

Liu C, Sage JC, Miller MR, Verhaak RG, Hippenmeyer S, Vogel H, Foreman O, Bronson RT, Nishiyama A, Luo L, et al. 2011. Mosaic analysis with double markers reveals tumor cell of origin in glioma. Cell 146: 209-221.

Liu X, Grogan TR, Hieronymus H, Hashimoto T, Mottahedeh J, Cheng D, Zhang L, Huang K, Stoyanova T, Park JW, et al. 2016. Low CD38 identifies progenitor-like inflammation-associated luminal cells that can initiate human prostate cancer and predict poor outcome. Cell Rep 17: 2596-2606.

Lu TL, Huang YF, You LR, Chao NC, Su FY, Chang JL, Chen CM. 2013. Conditionally ablated Pten in prostate basal cells promotes basal-to-luminal differentiation and causes invasive prostate cancer in mice. Am J Pathol 182: 975-991.

Lukacs RU, Memarzadeh S, Wu H, Witte ON. 2010. Bmi-1 is a crucial regulator of prostate stem cell self-renewal and malignant transformation. Cell Stem Cell 7: 682-693.

Moad M, Hannezo E, Buczacki SJ, Wilson L, El-Sherif A, Sims D, Pickard R, Wright NA, Williamson SC, Turnbull DM, et al. 2017. Multipotent basal stem cells, maintained in localized proximal niches, support directed long-ranging epithelial flows in human prostates. Cell Rep 20: 16091622.

Mulholland DJ, Xin L, Morim A, Lawson D, Witte O, Wu H. 2009. Lin $^{-}$Sca- $1^{+}$CD $499^{\text {digh }}$ stem/progenitors are tumorinitiating cells in the Pten-null prostate cancer model. Cancer Res 69: 8555-8562.

Mulholland DJ, Kobayashi N, Ruscetti M, Zhi A, Tran LM, Huang J, Gleave M, Wu H. 2012. Pten loss and RAS/ MAPK activation cooperate to promote EMT and metastasis initiated from prostate cancer stem/progenitor cells. Cancer Res 72: 1878-1889.

Ousset M, Van Keymeulen A, Bouvencourt G, Sharma N, Achouri Y, Simons BD, Blanpain C. 2012. Multipotent and unipotent progenitors contribute to prostate postnatal development. Nat Cell Biol 14: 1131-1138. 
Park JW, Lee JK, Phillips JW, Huang P, Cheng D, Huang J Witte ON. 2016. Prostate epithelial cell of origin determines cancer differentiation state in an organoid transformation assay. Proc Natl Acad Sci 113: 4482-4487.

Patrawala L, Calhoun T, Schneider-Broussard R, Zhou J, Claypool K, Tang DG. 2005. Side population is enriched in tumorigenic, stem-like cancer cells, whereas $\mathrm{ABCG} 2^{+}$ and $\mathrm{ABCG} 2^{-}$cancer cells are similarly tumorigenic. Cancer Res 65: 6207-6219.

Patrawala L, Calhoun T, Schneider-Broussard R, Li H, Bhatia B, Tang S, Reilly JG, Chandra D, Zhou J, Claypool K, et al. 2006. Highly purified $\mathrm{CD} 44^{+}$prostate cancer cells from xenograft human tumors are enriched in tumorigenic and metastatic progenitor cells. Oncogene 25: 1696-1708.

Patrawala L, Calhoun-Davis T, Schneider-Broussard R, Tang DG. 2007. Hierarchical organization of prostate cancer cells in xenograft tumors: The CD $44^{+} \alpha 2 \beta 1^{+}$cell population is enriched in tumor-initiating cells. Cancer Res 67: 6796-6805.

Pignon JC, Grisanzio C, Geng Y, Song J, Shivdasani RA, Signoretti S. 2013. p63-expressing cells are the stem cells of developing prostate, bladder, and colorectal epithelia. Proc Natl Acad Sci 110: 8105-8110.

Qin J, Liu X, Laffin B, Chen X, Choy G, Jeter CR, CalhounDavis T, Li H, Palapattu GS, Pang S, et al. 2012. The $\mathrm{PSA}^{-/ \mathrm{lo}}$ prostate cancer cell population harbors selfrenewing long-term tumor-propagating cells that resist castration. Cell Stem Cell 10: 556-569.

Richardson GD, Robson CN, Lang SH, Neal DE, Maitland NJ, Collins AT. 2004. CD133, a novel marker for human prostatic epithelial stem cells. J Cell Sci 117: 3539-3545.

Ruscetti M, Quach B, Dadashian EL, Mulholland DJ, Wu H. 2015. Tracking and functional characterization of epithelial-mesenchymal transition and mesenchymal tumor cells during prostate cancer metastasis. Cancer Res 75 : 2749-2759.

Rybak AP, Bristow RG, Kapoor A. 2015. Prostate cancer stem cells: Deciphering the origins and pathways involved in prostate tumorigenesis and aggression. Oncotarget 6 : 1900-1919.

Sachs N, de Ligt J, Kopper O, Gogola E, Bounova G, Weeber F, Balgobind AV, Wind K, Gracanin A, Begthel H, et al. 2018. A living biobank of breast cancer organoids captures disease heterogeneity. Cell 172: 373-386.

Sackmann Sala L, Boutillon F, Menara G, De Goyon-Pelard A, Leprevost M, Codzamanian J, Lister N, Pencik J, Clark A, Cagnard N, et al. 2017. A rare castration-resistant progenitor cell population is highly enriched in Pten-null prostate tumours. J Pathol 243: 51-64.

Samant MD, Jackson CM, Felix CL, Jones AJ, Goodrich DW, Foster BA, Huss WJ. 2015. Multi-drug resistance ABC transporter inhibition enhances murine ventral prostate stem/progenitor cell differentiation. Stem Cells Dev 24: 1236-1251.

Schepers AG, Snippert HJ, Stange DE, van den Born M, van Es JH, van de Wetering M, Clevers H. 2012. Lineage tracing reveals Lgr5 $^{+}$stem cell activity in mouse intestinal adenomas. Science 337: 730-735.

Shen MM, Abate-Shen C. 2010. Molecular genetics of prostate cancer: New prospects for old challenges. Genes Dev 24: 1967-2000.
Shibata M, Shen MM. 2013. The roots of cancer: Stem cells and the basis for tumor heterogeneity. Bioessays 35: 253260.

Shibata M, Shen MM. 2015. Stem cells in genetically-engineered mouse models of prostate cancer. Endocr Relat Cancer 22: T199-T208.

Siegel RL, Miller KD, Jemal A. 2018. Cancer statistics, 2018. CA Cancer J Clin 68: 7-30.

Signoretti S, Waltregny D, Dilks J, Isaac B, Lin D, Garraway L, Yang A, Montironi R, McKeon F, Loda M. 2000. p63 is a prostate basal cell marker and is required for prostate development. Am J Pathol 157: 1769-1775.

Signoretti S, Pires MM, Lindauer M, Horner JW, Grisanzio C, Dhar S, Majumder P, McKeon F, Kantoff PW, Sellers WR, et al. 2005. p63 regulates commitment to the prostate cell lineage. Proc Natl Acad Sci 102: 11355-11360.

Skvortsov S, Skvortsova II, Tang DG, Dubrovska A. 2018. Prostate cancer stem cells: Current understanding. Stem Cells doi: 10.1002/stem.2859.

Stoyanova T, Cooper AR, Drake JM, Liu X, Armstrong AJ, Pienta KJ, Zhang H, Kohn DB, Huang J, Witte ON, et al. 2013. Prostate cancer originating in basal cells progresses to adenocarcinoma propagated by luminal-like cells. Proc Natl Acad Sci 110: 20111-20116.

Sugimura Y, Cunha GR, Donjacour AA, Bigsby RM, Brody JR. 1986. Whole-mount autoradiography study of DNA synthetic activity during postnatal development and androgen-induced regeneration in the mouse prostate. Biol Reprod 34: 985-995.

Sutherland KD, Visvader JE. 2015. Cellular mechanisms underlying intertumoral heterogeneity. Trends Cancer $\mathbf{1}$ : $15-23$.

Szczyrba J, Niesen A, Wagner M, Wandernoth PM, Aumuller G, Wennemuth G. 2017. Neuroendocrine cells of the prostate derive from the neural crest. J Biol Chem 292: 2021-2031.

Taylor RA, Toivanen R, Frydenberg M, Pedersen J, Harewood L, Australian Prostate Cancer B, Collins AT, Maitland NJ, Risbridger GP. 2012. Human epithelial basal cells are cells of origin of prostate cancer, independent of CD133 status. Stem Cells 30: 1087-1096.

Thompson IM Jr, Goodman PJ, Tangen CM, Parnes HL, Minasian LM, Godley PA, Lucia MS, Ford LG. 2013. Long-term survival of participants in the prostate cancer prevention trial. N Engl J Med 369: 603-610.

Toivanen R, Shen MM. 2017. Prostate organogenesis: Tissue induction, hormonal regulation and cell type specification. Development 144: 1382-1398.

Toivanen R, Berman DM, Wang H, Pedersen J, Frydenberg M, Meeker AK, Ellem SJ, Risbridger GP, Taylor RA. 2011 Brief report: A bioassay to identify primary human prostate cancer repopulating cells. Stem Cells 29: 1310-1314.

Toivanen R, Frydenberg M, Murphy D, Pedersen J, Ryan A, Pook D, Berman DM, Taylor RA, Risbridger GP. 2013. A preclinical xenograft model identifies castration-tolerant cancer-repopulating cells in localized prostate tumors. Sci Transl Med 5: 187ra171.

Toivanen R, Mohan A, Shen MM. 2016. Basal progenitors contribute to repair of the prostate epithelium following induced luminal anoikis. Stem Cell Reports 6: 660-667. 
Tsujimura A, Koikawa Y, Salm S, Takao T, Coetzee S, Moscatelli D, Shapiro E, Lepor H, Sun TT, Wilson EL. 2002. Proximal location of mouse prostate epithelial stem cells: A model of prostatic homeostasis. J Cell Biol 157: 1257-1265.

van de Wetering M, Francies HE, Francis JM, Bounova G, Iorio F, Pronk A, van Houdt W, van Gorp J, Taylor-Weiner A, Kester L, et al. 2015. Prospective derivation of a living organoid biobank of colorectal cancer patients. Cell 161: 933-945.

van den Hoogen C, van der Horst G, Cheung H, Buijs JT, Lippitt JM, Guzman-Ramirez N, Hamdy FC, Eaton CL, Thalmann GN, Cecchini MG, et al. 2010. High aldehyde dehydrogenase activity identifies tumor-initiating and metastasis-initiating cells in human prostate cancer. Cancer Res 70: 5163-5173.

Vander Griend DJ, Karthaus WL, Dalrymple S, Meeker A, DeMarzo AM, Isaacs JT. 2008. The role of CD133 in normal human prostate stem cells and malignant cancer-initiating cells. Cancer Res 68: 9703-9711.

Visvader JE. 2011. Cells of origin in cancer. Nature 469: 314322.

Visvader JE, Clevers H. 2016. Tissue-specific designs of stem cell hierarchies. Nat Cell Biol 18: 349-355.

Wang ZA, Shen MM. 2011. Revisiting the concept of cancer stem cells in prostate cancer. Oncogene 30: 1261-1271.

Wang X, Kruithof-de Julio M, Economides KD, Walker D, Yu HL, Halili MV, Hu YP, Price SM, Abate-Shen C, Shen MM. 2009. A luminal epithelial stem cell that is a cell of origin for prostate cancer. Nature 461: 495-500.

Wang ZA, Mitrofanova A, Bergren SK, Abate-Shen C, Cardiff RD, Califano A, Shen MM. 2013. Lineage analysis of basal epithelial cells reveals their unexpected plasticity and supports a cell-of-origin model for prostate cancer heterogeneity. Nat Cell Biol 15: 274-283.

Wang J, Zhu HH, Chu M, Liu Y, Zhang C, Liu G, Yang X, Yang R, Gao WQ. 2014a. Symmetrical and asymmetrical division analysis provides evidence for a hierarchy of prostate epithelial cell lineages. Nat Commun 5: 4758.

Wang ZA, Toivanen R, Bergren SK, Chambon P, Shen MM. 2014b. Luminal cells are favored as the cell of origin for prostate cancer. Cell Rep 8: 1339-1346.

Wang BE, Wang X, Long JE, Eastham-Anderson J, Firestein R, Junttila MR. 2015. Castration-resistant $\mathrm{Lgr}^{+}$cells are long-lived stem cells required for prostatic regeneration. Stem Cell Reports 4: 768-779.

Watson PA, Arora VK, Sawyers CL. 2015. Emerging mechanisms of resistance to androgen receptor inhibitors in prostate cancer. Nat Rev Cancer 15: 701-711.
Wei X, Orjalo AV, Xin L. 2016. CD133 does not enrich for the stem cell activity in vivo in adult mouse prostates. Stem Cell Res 16: 597-606.

Wuidart A, Ousset M, Rulands S, Simons BD, Van Keymeulen A, Blanpain C. 2016. Quantitative lineage tracing strategies to resolve multipotency in tissue-specific stem cells. Genes Dev 30: 1261-1277.

Xin L. 2013. Cells of origin for cancer: An updated view from prostate cancer. Oncogene 32: 3655-3663.

Xin L, Ide H, Kim Y, Dubey P, Witte ON. 2003. In vivo regeneration of murine prostate from dissociated cell populations of postnatal epithelia and urogenital sinus mesenchyme. Proc Natl Acad Sci 100: 11896-11903.

Xin L, Lawson DA, Witte ON. 2005. The Sca-1 cell surface marker enriches for a prostate-regenerating cell subpopulation that can initiate prostate tumorigenesis. Proc Natl Acad Sci 102: 6942-6947.

Xin L, Lukacs RU, Lawson DA, Cheng D, Witte ON. 2007. Self-renewal and multilineage differentiation in vitro from murine prostate stem cells. Stem Cells 25: $2760-$ 2769.

Yoo YA, Roh M, Naseem AF, Lysy B, Desouki MM, Unno K, Abdulkadir SA. 2016. Bmil marks distinct castration-resistant luminal progenitor cells competent for prostate regeneration and tumour initiation. Nat Commun 7: 12943.

Zhang D, Lin K, Lu Y, Rycaj K, Zhong Y, Chao HP, Calhoun-Davis T, Shen J, Tang DG. 2017. Developing a novel two-dimensional culture system to enrich human prostate luminal progenitors that can function as a cell of origin for prostate cancer. Stem Cells Transl Med 6: 748760.

Zhang D, Jeter C, Gong S, Tracz A, Lu Y, Shen J, Tang DG. 2018. Histone 2B-GFP label-retaining prostate luminal cells possess progenitor cell properties and are intrinsically resistant to castration. Stem Cell Reports 10: 228242.

Zhao SG, Chang SL, Erho N, Yu M, Lehrer J, Alshalalfa M, Speers C, Cooperberg MR, Kim W, Ryan CJ, et al. 2017. Associations of luminal and basal subtyping of prostate cancer with prognosis and response to androgen deprivation therapy. JAMA Oncol 3: 1663-1672.

Zou M, Toivanen R, Mitrofanova A, Floch N, Hayati S, Sun Y, Le Magnen C, Chester D, Mostaghel EA, Califano A, et al. 2017. Transdifferentiation as a mechanism of treatment resistance in a mouse model of castration-resistant prostate cancer. Cancer Discov 7: 736-749. 


\section{$\&_{\mathrm{CSH}}^{\infty} \&$ Cold Spring Harbor

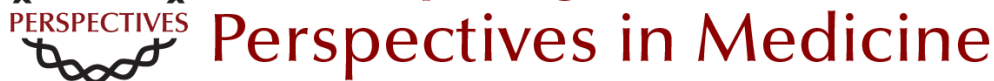

\section{Prostate Stem Cells and Cancer Stem Cells}

Jia J. Li and Michael M. Shen

Cold Spring Harb Perspect Med 2019; doi: 10.1101/cshperspect.a030395 originally published online October 5, 2018

\section{Subject Collection Prostate Cancer}

Anatomic and Molecular Imaging in Prostate Cancer

Eric T. Miller, Amirali Salmasi and Robert E. Reiter

The Epidemiology of Prostate Cancer

Claire H. Pernar, Ericka M. Ebot, Kathryn M. Wilson, et al.

Prostate Stem Cells and Cancer Stem Cells Jia J. Li and Michael M. Shen

Prostate Cancer Epigenetics: From Basic Mechanisms to Clinical Implications Srinivasan Yegnasubramanian, Angelo M. De Marzo and William G. Nelson

\section{The Genomics of Prostate Cancer: A Historic} Perspective Mark A. Rubin and Francesca Demichelis

Neuroendocrine Differentiation in Prostate

Cancer: Emerging Biology, Models, and Therapies Loredana Puca, Panagiotis J. Vlachostergios and Himisha Beltran

DNA Damage Response in Prostate Cancer Matthew J. Schiewer and Karen E. Knudsen

Transcriptional Regulation in Prostate Cancer David P. Labbé and Myles Brown
New Opportunities for Targeting the Androgen Receptor in Prostate Cancer Margaret M. Centenera, Luke A. Selth, Esmaeil Ebrahimie, et al.

Prostate Cancer Research at the Crossroads Michael M. Shen and Mark A. Rubin

Immunotherapy for Prostate Cancer Nicholas J. Venturini and Charles G. Drake

Molecular Pathology of High-Grade Prostatic Intraepithelial Neoplasia: Challenges and Opportunities Levent Trabzonlu, Ibrahim Kulac, Qizhi Zheng, et al.

Metastases in Prostate Cancer Federico La Manna, Sofia Karkampouna, Eugenio Zoni, et al.

Genetically Engineered Mouse Models of Prostate Cancer in the Postgenomic Era Juan M. Arriaga and Cory Abate-Shen

Molecular Biomarkers in the Clinical Management of Prostate Cancer Aaron M. Udager and Scott A. Tomlins

Metabolic Vulnerabilities of Prostate Cancer: Diagnostic and Therapeutic Opportunities Giorgia Zadra and Massimo Loda

For additional articles in this collection, see http://perspectivesinmedicine.cshlp.org/cgi/collection/ 